\title{
Appraisal of Groundnut Marketing in Yamaltu Deba Local Government Area of Gombe State, Nigeria
}

\author{
Erie $\mathrm{GO}^{2}$, Aina $\mathrm{OS}^{1 *}$ and $\mathrm{Odegbade} \mathrm{OO}^{3}$ \\ ${ }^{1}$ Department of Cooperative Economics and Management, Federal College of Horticulture, Nigeria \\ ${ }^{2}$ Department of Agricultural Economics and Extension, Ambrose Alli University, Nigeria \\ ${ }^{3}$ Federal Government Girls' College, Nigeria
}

Submission: May 07, 2019; Published: June 28, 2019

*Corresponding author: Aina OS, Department of Agricultural Economics and Extension, Faculty of Agriculture, Ambrose Alli University, Ekpoma, Edo State, Nigeria

\begin{abstract}
The study carried out an appraisal of groundnut marketing in Yamaltu Deba Local Government Area of Gombe State. It specifically examined the socio-economic characteristics of groundnut marketers in the study area, determined profitability, examining market structure and analyzed the constraints to groundnut marketing in the study area. Primary data were collected from 70 groundnut marketers using two-stage sampling technique and structured questionnaire administered to them. Data collected were analyzed using descriptive statistics, gross margin analysis, Gini-Coefficient and market structure analysis. The studies revealed that majority (61.43\%) of the respondents were male, married (37.14\%) and had western education (84.29\%). The profitability analysis showed that an average markers incurred a total variable cost N16,161,500 but earned an average revenue of N294,971.43 over the same period; and indication that an average marketer earned N64,092.86 as gross margin per year; suggesting that groundnut marketing is profitable venture in the study area. A Gini-coefficient of 0.48055 obtained in the study indicates a high level of concentration in the groundnut market. The major constraints to groundnut marketing are transportation, low demand and poor storage. It is recommended that transportation should be improved in term of good roads and storage facilities should be provided with subsidies insecticides to enhance more profit to the marketers.
\end{abstract}

Keywords: Appraisal; Groundnut; Marketing; Gombe; Nigeria

\section{Introduction}

Agricultural marketing is the process by which product flow, physically and economically from the producer to the final consumer in order to create exchange that satisfy the objective of industry, organization and the society. This marketing leads to the creation of farm product, place and time utility. (khols and Downey 1972) [1-3]. Khol \& Downey [4] stated that agricultural marketing is concern with those productive activities that involve time, place, form and possession utility to agriculture commodities. The marketing of goods involves the movement of goods through intermediary in orderly manner to consumer. Individual business organization is all involving the task of moving the product from the point of production to the point of consumption [3]. According to Adegeye \& Dittoh [5] in subsistence economic where little or no exchange takes place marketing does not occupy any significant position. However, as the economic become increasingly commercialized leading to the growth other area, like urban wages earners marketing assumes greater important. This is because the excess production from the farm must be disposed of, in order to earn some income with which the farmers can purchase other goods and services not produced by them. Olukosi \& Isitor [3]. Other importance of marketing according to Marion \& Hardy [6] include the following:

a) Creation of job opportunity: marketing offer opportunity for rapid growth and advancement. A careful study of marketing will give the study a better idea about business and where the best opportunity for career.

b) Relate needs and desire of people with the producer product of enjoyment of service.

c) Marketing activities are used in many organizations: a variety of interesting challenging career opportunity are available in the marketing field some of these are personal activities, packaging, transporting, storage marketing whole selling and retailing

d) Marketing activities persuade our everyday lives, it also allows us to achieve many improvements in the quality of our lives 
e) Marketing cost a sizeable part of buyer's money. The study of marketing activities will make you to be aware of marketing activities cost money: most of the money is censured in market.

Considering the importance of agricultural marketing, Adegeye \& Dittoh [5] opined that its study should be given priority in most developing nation. According to them as the economy grow, agricultural marketing will become more and more complete and it efficient will then depend on the "manager" of the marketing system who themselves must be well informed about what it takes to have an efficient marketing system.

Groundnut (Arachis hypogaea) is widely eaten and used for making ground nut oil, ground nut butter, salted groundnut and number of confectionaries tops peanut can die, brittle crispe Carmel tops, peanut candy, bakery sweet Holadey (1979) and Osuji [7].

Clodius \& Mueller [8] revealed that groundnut can also be processed to produced groundnut cheese peanut protein, peanut milk. Peanut paste for seasoning vegetable boiled unshelled fresh peanut and peanut bread Osuji [7] stated that groundnut contain about $11 \%$ carbohydrate, $30 \%$ protein, $45 \%$ oil, $2 \%$ Ash and $5 \%$ water. After oil extraction, the residues are good source of protein useful in bakeries and in manufacture of livestock feeds. The most commercial product of groundnut is peanut candy which is sold in supermarket or hawked in the street.

Groundnuts or peanuts as they are sometimes called, originated in Brazil they are one of the most valuable legume crops of tropical and sub-tropical countries. They are both a food crop and a cash crop they are exported mainly for their oil groundnut oil is used in making margarine, cooking, salad oils and soap. After the oil has been extracted, a dry cake is left with a valuable, protein - rich for livestock feed. The dry cake can also be rolled into rings and fried in oil to produce "kuli - kuli".

Nigeria was until 1974 the world's leading exporter of groundnuts. Senegal, Gambia, and Niger are the other important West African producers of this crop.

The broad objective of the study is appraising groundnut system marketing in Yamaltu Deba LGA of Gombe state. The specific objectives are to: Determine the socio-economic characteristic of respondents in the study area, determine the groundnut seller structure in the study area, evaluate costs and returns of groundnut marketing and identify the constraints associated with groundnut marketing in the study area.

\section{Methodology}

\section{Description of the study area}

The study was carried out in Yamaltu Deba Local Government Area of Gombe State, located in north-eastern Nigeria. Yamaltu Deba local government share border with Bayo local government of Borno state to the North, Balanga, to the south, Gombe and
Akko local government to the east. Yamaltu Deba L.G.A has the total land area of 1,981km (765)3\% m and population 255, 248.

The study area located at latitude of $11030 \mathrm{~N}$, longitude 100 $20 \mathrm{E}$ and latitude of $24 \mathrm{~m}$ above the sea level, the area received total annual rainfall of the about $760-1100 \mathrm{~mm}$ per annum and temperature ranges between $240 \mathrm{c}$ to $480 \mathrm{c}$. The soil type is loam, clay, clay loam soil that is suitable for most crops. The area consists of two (2) major seasons namely the rainy season and the dry season. The rainy season start from April and ends in September while the dry season starts October and end in March. The people in the area of study involved in both rainy and dry season farming the result of the high temperature give room for high evaporation and thus less moisture available for plant.

Crops grown in the area are groundnut, maize, millet. Local government comprises of nineteen (19) district namely Kwadon, Zambuk, Kurba, Hinna, Liji, Wade, Shinga, Gwani, Kinafa, Gwali, Lano, Kuri, Dumbu, Jagali, Kurjale, Lubo, Difa, Dadin-kowa and Deba. The occupants are mostly Tera and other tribes are Yoruba, Igbo and Fulani the main occupation of the inhabitant is mostly farming and trading very few are civil and public servants.

\section{Sampling size and technique}

A multistage random sampling technique will be adopted to select four (4) markets in the study area. The four (4) markets selected are Kwadon, Dadin-kowa, Kuri and Zambuk. Out of the four (4) markets selected 20 marketers were selected to give a total number of 80 respondents that were used for the study.

\section{Method of data collection}

Primary data were collected using structured questionnaire and oral interview, the information contained in the primary data include the socio - economic characteristics of the respondent such as age, sex and educational qualification.

\section{Analytical techniques}

Simple descriptive statistics such as mean score, frequency count and percentage range were used to satisfy objective 1 , and 4 while market margin analysis was used to satisfy objective 3 of the study and Gini coefficient was used for objective (2). The model is express as follows:

The market margin for objective 3 is expressed as.

$$
\begin{aligned}
& \mathrm{Sp}=\mathrm{cp} \times 100 / 1 \\
& \mathrm{Sp}=\text { selling price } \\
& \mathrm{Cp}=\text { cost price } \\
& \mathrm{Mm}=\text { market margin } \\
& \text { Gini coefficient }(\mathrm{GC})=(\mathrm{xy}) \text { where: } \\
& \mathrm{X}=\text { proportion of seller } \\
& \mathrm{Y}=\text { cumulative proportion of sales/ income }
\end{aligned}
$$


Results and Discussion

Table 1: Socio-economic characteristics of the respondents.

\begin{tabular}{|c|c|c|}
\hline Variables & Frequency & Percentage \\
\hline \multicolumn{3}{|l|}{ Gender } \\
\hline Male & 43 & 61.43 \\
\hline Female & 27 & 38.57 \\
\hline \multicolumn{3}{|l|}{ Marital Status } \\
\hline Single & 24 & 34.29 \\
\hline Married & 26 & 37.14 \\
\hline Divorced & 10 & 14.29 \\
\hline Widow & 10 & 14.29 \\
\hline \multicolumn{3}{|l|}{ Household Size } \\
\hline $1-5$ & 15 & 21.43 \\
\hline $6-10$ & 35 & 50 \\
\hline $11-15$ & 20 & 28.57 \\
\hline \multicolumn{3}{|l|}{ Educational Background } \\
\hline Never been to School & 4 & 5.71 \\
\hline Primary Education & 10 & 14.29 \\
\hline Secondary Education & 24 & 34.29 \\
\hline Adult Education & 8 & 11.43 \\
\hline Tertiary Education & 17 & 24.29 \\
\hline Qur'an Education & 7 & 10 \\
\hline \multicolumn{3}{|l|}{ Source of Capital } \\
\hline Personal Savings & 41 & 58.57 \\
\hline Cooperatives & 20 & 28.57 \\
\hline Loan from the Bank & 2 & 2.86 \\
\hline Friends and Relatives & 7 & 10 \\
\hline \multicolumn{3}{|l|}{ Experience in Years } \\
\hline $0-5$ & 8 & 11.43 \\
\hline $6-10$ & 39 & 55.71 \\
\hline $11-15$ & 15 & 21.43 \\
\hline $16-20$ & 5 & 7.14 \\
\hline 21 and above & 3 & 4.29 \\
\hline
\end{tabular}

Source: Field Survey, 2016.

Socio-economic characteristics are known to influence the decision behavior of the respondents [9]. Such demographic variables considered are; Gender, Marital status, Household size, Education background, Source of income, Experience in groundnut marketing.

Table 1 Shows that $61.43 \%$ of the respondents were male and $38.57 \%$ were female. This shows that majority of the respondents in groundnut marketing in the study area were male as a result of catering for their family needs. And this also since most of the women are in purdah because they are Muslim. The field survey data also shows that $37.14 \%$ of respondent were married while $34.29 \%$ were single, widows and divorce were $28.58 \%$. This shows that majority of the marketers were married and have family responsibilities. Household size is an important source of family labour. Majority (78.57\%) of the respondents have their household size, greater than five. The modal household size is 6-10.

The Field survey data shows that $84.29 \%$ of the respondents had western education and $10 \%$ had Qur'anic education this shows that majority of groundnut marketers are literate and have access to information which in turn will affect their decision making positively. Majority (58.57\%) source their capital through personal savings; while $28.57 \%$ and $10 \%$ source their capital through cooperative, friends and relatives respectively. Only $2.86 \%$ source their capital from the bank. The results indicate that majority of the respondents got their capital source through personal saving and the capital from this source is usually very small. This may be one of the reasons why they trade on a small scale. The study also revealed that the average numbers of years of groundnut marketing experience is 10 years and $88.57 \%$ of the respondents have an experience above five years while $11.43 \%$ are below 5 years. This indicated that the respondents are experienced in groundnut marketing.

Gini co-efficient $=1-\sum x y$

$$
\begin{aligned}
& =1-0.51945 \\
& =0.48055
\end{aligned}
$$

The Gini-coefficient for groundnut market in the study area shown in Table 2 was 0.48055 . This result indicates a high level of concentration and consequently high inefficiency in the market structure for groundnuts in the study area. This was in line with Dillion \& Hardaker [10] in their finding that the value of Gini-co-efficient greater that 0.35 is high indicating inequitable distribution of sales.

Table 2: Composition of Gini Coefficient for Groundnut Marketing in the Study Area.

\begin{tabular}{|c|c|c|c|c|c|c|c|}
\hline $\begin{array}{c}\text { Income } \\
\text { Sales (N) }\end{array}$ & $\begin{array}{c}\text { Number of } \\
\text { Sellers }\end{array}$ & $\begin{array}{c}\text { Proportion } \\
\text { of Sellers (x) }\end{array}$ & $\begin{array}{c}\text { Cumulative } \\
\text { Proportion of Sellers }\end{array}$ & $\begin{array}{c}\text { Total Sales } \\
\text { (N) }\end{array}$ & $\begin{array}{c}\text { Proportion of } \\
\text { Sales }\end{array}$ & $\begin{array}{c}\text { Cumulative } \\
\text { Proportion of Sales } \\
\text { (y) }\end{array}$ & $\begin{array}{c}\text { Xy } \\
\mathbf{5} 100,000\end{array}$ \\
\hline $\begin{array}{c}100,001- \\
150,000\end{array}$ & 5 & 0.06 & 0.06 & 330,000 & 0.016 & 0.016 & 0.00096 \\
\hline $\begin{array}{c}150,001- \\
200,000\end{array}$ & 7 & 0.1 & 0.13 & 670,000 & 0.032 & 0.048 & 0.00336 \\
\hline $\begin{array}{c}200,001- \\
250,000\end{array}$ & 10 & 0.14 & 0.23 & $1,210,000$ & 0.059 & 0.107 \\
\hline
\end{tabular}




\section{International Journal of Environmental Sciences \& Natural Resources}

\begin{tabular}{|c|c|c|c|c|c|c|c|}
\hline $\begin{array}{c}250,001- \\
300,000\end{array}$ & 14 & 0.2 & 0.57 & $3,818,000$ & 0.185 & 0.404 & 0.0808 \\
\hline $\begin{array}{c}300,001- \\
350,000\end{array}$ & 2 & 0.03 & 0.6 & 720,000 & 0.035 & 0.439 \\
\hline $\begin{array}{c}350,001- \\
400,000\end{array}$ & 3 & 0.04 & 0.64 & $1,165,000$ & 0.056 & 0.495 & 0.0198 \\
\hline$\geq 400,001$ & 25 & 0.36 & 1 & $10,420,000$ & 0.505 & 1 \\
\hline Total & 70 & 1 & & $20,648,000$ & & 0.36 \\
\hline
\end{tabular}

Source: Computed from Field Survey Data, 2016.

Table 3: Composition of Gini Coefficient for Groundnut Marketing in the Study Area.

\begin{tabular}{|c|c|c|}
\hline Items & Cost N & \% of TVC \\
\hline Cost of storage & 12,100 & 0.07 \\
\hline Tax/levy & 25,900 & 0.16 \\
\hline Cost of purchase & $15,112,000$ & 93.51 \\
\hline Cost of labour & 431,000 & 2.67 \\
\hline Cost of transportation & 580,500 & 3.59 \\
\hline Total variable cost (TVC) & $16,161,500$ & 100 \\
\hline Total Revenue (TR) & $20,648,000$ & \\
\hline Gross Margin (GM= TR-TVC) & $4,486,500$ & \\
\hline Average Total Variable Cost (TVC/N) & $230,878.57$ & \\
\hline Average Total Revenue (TR/N) & $294,971.43$ & \\
\hline Average Gross Margin (GM/N) & $64,092.86$ & \\
\hline
\end{tabular}

Source. Field Survey, 2016.

The result in Table 3 showed that acquisition cost gulped $93.5 \%$ of the total variable cost, while the cost of labour accounted for $2.67 \%$ of the total variable cost. The cost of storage accounted for $0.07 \%$ of the total variable cost while tax/ levy accounted for $0.16 \%$ of the total variable cost. Only $3.59 \%$ of the total variable cost was expended on transportation. The table also revealed that an average marketer incurred a total variable cost of $\mathrm{N} 16,161,500$ but earned an average revenue of N294,971.43 over the same period. This indicate that an average marketer earned N64,092.86 as gross margin per year,

suggesting that groundnut marketing is profitable venture in the study area.

The analysis revealed in Table 4, shows that transportation problem ranked first of the constraints considered. One possible explanation for this is that marketers travel long distance to meet consumers residing in urban areas. The distance to the point of sales could affect the quality and cost of groundnut which consequently increase the marketing cost and thereby reducing the profit margin. Next to transportation was low demand occasioned by price variation. Third in the ranking was poor storage which can affect the quality if not properly stored with good insecticides, pesticides and in-turn affect the sale price. The time period between harvesting and consumption brings about the need for storage. Spoilage remains the consequences of poor storage. This is supported by most of the groundnut marketers who claimed storage problem constitutes a very serious problem in groundnut marketing. Table 4 also revealed that thefts and access to adequate loan is a serious problem in groundnut marketing. This is also supported by the fact that most groundnut marketers finance their business through personal savings. Given the low income of the marketers only little can be expected from their savings. Climatic factors constitute a serious problem to groundnut marketers in the study area. Climatic factor like sunlight, humidity and rainfall affect groundnut after harvesting. They are also affected between the period of harvest and distribution period to consumers. Unavailability of laboured was also considered.

Table 4: Constraint analysis of groundnut marketing in the study area.

\begin{tabular}{|c|c|c|c|c|c|c|c|c|c|c|c|}
\hline \multirow{2}{*}{ Constraint } & \multicolumn{3}{|c|}{ Very serious } & \multicolumn{3}{c|}{ Serious } & \multicolumn{3}{c|}{ Not a Problem } & Final Weight & Rank \\
\cline { 2 - 12 } & Scores & Frequency & Weight & Scores & Frequency & Weight & Score & Frequency & Weight & 5 th \\
\hline $\begin{array}{c}\text { Lack of access } \\
\text { to credit }\end{array}$ & 3 & 8 & 24 & 2 & 38 & 76 & 1 & 24 & 24 & 124 \\
\hline $\begin{array}{c}\text { Climatic } \\
\text { problem }\end{array}$ & 3 & 2 & 6 & 2 & 49 & 98 & 1 & 19 & 19 & 123 \\
\hline $\begin{array}{c}\text { Poor } \\
\text { transportation }\end{array}$ & 3 & 58 & 174 & 2 & 8 & 16 & 1 & 4 & 4 & 194 & 1 st \\
\hline Poor storage & 3 & 10 & 30 & 2 & 52 & 104 & 1 & 8 & 8 & 142 & $3 \mathrm{nd}$ \\
\hline Low demand & 3 & 24 & 72 & 2 & 36 & 72 & 1 & 10 & 10 & 154 & $2 \mathrm{nd}$ \\
\hline $\begin{array}{c}\text { Unavailability } \\
\text { of labour }\end{array}$ & 3 & 0 & 0 & 2 & 12 & 24 & 1 & 58 & 58 & 82 & 7 th \\
\hline Theft & 3 & 12 & 36 & 2 & 37 & 74 & 1 & 21 & 21 & 131 & 4 th \\
\hline
\end{tabular}

Source. Computed from Field Survey Data, 2016. 


\section{Conclusion}

Most groundnut marketers were male, married, experienced, literate and source their capital through personal savings. Groundnut marketing is profitable ventures in the study area with high level of concentration in the groundnut market. The major constrains to groundnut marketing in the study area are transportation, low demand, poor storage, theft and lack of access to credit.

\section{Recommendation}

Based on the findings of this study the following recommendations were made.

a) In order to curtail the problem of inadequate capital, development bank such as Nigerian Agricultural Cooperative Banks or micro finance bank and other commercial bank should encourage the groundnut marketer by grant loan at low interest rate in order to empower the marketers to improved and expand their business.

b) Poor transportation; There is need for local government to construct durable road in the rural area where all agricultural products are produced in order to link them with market and other points. This will help to increase the availability of groundnut and therefore reduce the cost of transportation.

c) Poor storage (Market facilities) can be tackling through government assistance in constructing market structures and provides other market facilities in the study area, to facilitate market activities in general and groundnut marketing. That is improving storage facilities of groundnut should be provided for the marketers by the government and co-operatives should also assists in building storage facilities to the marketers, this will help to curtail the loss of groundnut.

d) The problem of low demand of groundnut received by the marketers, the government should promote the transportation of the commodity and boost the purchasing power of local consumers.

\section{References}

1. Adekanya TO (1988) Reading in agricultural marketing, Longman Nigeria Limited, p. 6.

2. Abbo JC, Makeham JP (1990) Agricultural economic and marketing in the tropic's international tropical agricultural series. Longman, London.

3. Olukosi JO, Isuitor SU (1990) Introduction to agricultural marketing and prices principles and application. Living Books Series G.U. Production, Abuja FCT, Nigeria.

4. Kohls RL, Downey WD (1980) Marketing of agricultural products. Edition Macmillan, New York.

5. Adegeye AJ, Dittoh JS (1985) Essential of agricultural economics, Impact Publishers Nigeria Limited, Ibadan, pp. 164, 179-189.

6. Marion BW, Handy CR (2003) Market performance: concept and measure.

7. Osuji G (2005) Aelorness in groundnut research. published by biochemical society of nigeria in collaboration with Anambara state University of Technology, p. 5.

8. Clodius RL, Mueller WF (2009) Market structure analysis as an orientation for research in agricultural economics in CL Miller Edition, Marketing and Economic Development, Lincoln University of Braska press, p. 345 .

9. Dittoh N (1996) Intermediate economics. Macmillan Press L.T.D, London, p. 20

10. Dillion JI, Handaker JB (1993) Farm management research for small farmer development, Rome. 